\title{
Labor Migration from Third Countries to Swedish Low-wage Jobs'
}

\section{Olle Frödin}

Associate professor, Lund University, Department of Sociology, Sweden

\section{Anders Kjellberg ${ }^{2}$}

Professor, Lund University, Department of Sociology, Sweden

\begin{abstract}
Since December 2008, Sweden has more liberal rules for labor immigration from 'third countries' - countries outside the European Union (EU) and European Economic Area (EEA) - than any other country in the Organisation for Economic Co-operation and Development (OECD). The introduction of employer-driven labor immigration, motivated by the need to address labor shortages, resulted in large inflows of migrants in low-skilled occupations in labor surplus sectors. This article examines the situation of the approximately 500 restaurant and cleaning workers who were granted work permits in Stockholm in 201 2. More than four out of ten labor migrants 'switched track' from asylum seekers, students, or family connection. Every second worker was recruited to companies without collective agreements. In several cases, a nationality/ethnic link between migrant and employer appears to exist. The reasons why so many low-skilled labor migrants in nonseasonal occupations were recruited are discussed. Finally, alternative explanations for the decline of this type of labor migration after 2011 are considered.
\end{abstract}

\section{KEYWORDS}

Asylum / cleaning / labor migration / restaurants / Stockholm / work permit

\section{INTRODUCTION}

weden is famous for its high union density and collective agreement coverage. However, in the last few decades, the Swedish labor market model has been put under increasing pressure. Union density has declined considerably among bluecollar workers. The employment gap between native-born and foreign-born residents is one of the largest among the European OECD countries (OECD, 2015:69). Considering the poor labor market integration of foreign-born residents, a seemingly paradoxical labor immigration reform was launched in 2008 making Sweden 'the most open labor migration system among OECD countries' (OECD, 2011:11).

Prior to the reform, Sweden applied restrictive rules based on labor market tests, designed to eliminate temporary bottlenecks and shortages of high-skilled labor. Since December 2008, Swedish employers have been free to recruit third-country nationals for any occupation and sector. This significantly curtailed trade union influence on labor immigration practices. The new migration system relies on the idea that employers

\footnotetext{
${ }^{1}$ You can find this text and its DOI at https://tidsskrift.dk/njwls/index

${ }^{2}$ Corresponding author: anders.kjellberg@soc.lu.se
} 
recruit third-country nationals only if they cannot find any EU residents to employ. The government bill argued that there was no risk that companies would prefer foreign workers to domestic labor, because 'from an employer perspective [it] usually is much easier to recruit from Sweden than from third countries, provided that the right skills are available within the country' (Government bill, 2007/2008:147, p. 26). The government argued that the 'main driving force' for the 2008 reform was the labor shortages that could not 'be filled solely by people living in Sweden or other EEA countries' (Emilsson 2016:10).

Berg and Spehar (2013) explain the Swedish labor immigration reform as being the result of an unholy alliance between the Green Party, advocating cultural cosmopolitanism and a world without borders, and the four center-right parties seeking to increase labor mobility and maximize freedom for employers. The needs of small and mediumsized enterprises were stressed by the Center Party. In 2002, the five parties, together with the Confederation of Swedish Enterprise (SN), launched a campaign to relax Sweden's strict labor migration policies. The original initiative was taken by $\mathrm{SN}$, which raised the question in 2001 and in 2002 presented a concrete proposal that became fundamental for the continued discussion (Johansson, 2014:108-111). Boräng and Cerna (2017) attribute this development to changed power relations between employers and trade unions, and diverging views between the blue-collar LO and the white-collar TCO and Saco. Due to shortages of graduate engineers and other categories of skilled workers, the latter confederations showed a more open attitude to labor immigration than did LO.

Johansson (2014) highlights the diverging interests of employers and unions: a market liberal policy aimed at employer control over labor immigration as opposed to a restrictive policy to avoid wage dumping. With changed power relations, the employers' perspective became more influential in the parliamentary arena, which was also characterized by power shifts and new coalitions.

In the years following the reform, numerous third-country migrants were recruited, not only to shortage occupations but also to low-skilled occupations without labor shortages. This prompted OECD to express concern and to call for closer monitoring of the reform outcome including the following aspects:

- whether the increasing recruitment into low-skilled occupations was related to regional shortages, for example, in Stockholm;

- whether companies run by immigrants tended to recruit co-nationals;

- the extent to which employers recruiting migrants in surplus occupations had signed collective agreements (OECD, 2011:13, 19, 88).

According to the law, the employment conditions of third-country labor migrants must not be below the minimum level of the collective agreement or the praxis in the sector. In contrast to most other EU countries, Sweden has neither statutory minimum wages, nor any mechanisms to extend collective agreements to whole sectors. This gives trade unions a key role in promoting decent employment conditions, but as OECD remarks, 'it is difficult for trade unions to play a role in monitoring employers and workplaces not covered by collective agreements' (OECD, 2011:126). The informal veto previously held by unions was used to 'block recruitment by firms in which they had little oversight'.

Part of the demand for labor immigrants is explained by a shortage of domestic labor available for high-skilled jobs such as computer specialists and for low-skilled seasonal 
jobs such as berry-pickers. However, a third category of labor immigrants was recruited in large numbers to low-skilled jobs in surplus occupations. Of the 16,500 work permits granted in 2012 (including extensions), 'elementary occupations' accounted for 7200 (of which 5700 were berry pickers and planters) and highly skilled professionals for 6100 . In 2016, the latter accounted for half of the work permits.

In recent decades, the number of low-skilled and low-paid service jobs has grown in the increasingly polarized Swedish labor market, but the competition to get such jobs is fierce and from an employer perspective 'the supply of persons available for jobs in the low-wage sector has been beneficial' (Åberg, 2012:21). These jobs are competed for not only by persons with low education, students, and other young people, but also by highly educated individuals who have failed to get jobs corresponding to their level of education. Furthermore, a rapidly growing share of the low-paid service jobs is held by foreign-born residents.

\section{AIMS, HYPOTHESES, DATA, AND METHODS}

The primary objective of this article is to explain why so many third-country nationals were recruited to sectors characterized by high unemployment and a large share of lowskilled jobs. Although the introduction of the new labor migration legislation coincided with the financial crisis, a marked influx of labor migrants to the restaurants and cleaning sectors occurred in the years following the reform. For this reason, we have chosen these sectors for a closer study.

A first bypothesis is that the new legislation has put third-country labor migrants in a considerably more subordinate and vulnerable position than other employees, which might make them attractive for employers who seek to exploit this weak position. During the first two years of a work permit, the labor migrant is bound to a specific employer and occupation. If the migrant loses the job, expulsion from Sweden will follow unless a new job in the same occupation is found within a few months and a new work permit is granted. After four years, the labor migrant normally receives a permanent residence permit. In the meantime, the migrant may be prepared to accept worse working conditions than promised in the work offer, which is not legally binding. It can be argued that the legislation produces such unequal balances of power that the concept of unfree labor would be appropriate to describe the position of many third-country labor migrants. In addition, the power relations between employers and labor migrants are influenced by the weak market position of unskilled workers in sectors distinguished by high unemployment. The risk of being exploited could be expected to be greatest in companies without collective agreements. In such situations, unions have virtually no ability to control working conditions. Furthermore, Sweden has no equivalence to the Norwegian Labor Inspection Authority, which has significant powers to inspect working and employment conditions.

By its very construction, the 2008 labor migration legislation put unskilled labor migrants in surplus occupations into a vulnerable position. Therefore, the absence of a collective agreement could be expected to make this category of workers more vulnerable to abuse than other foreign-born workers, not to mention native Swedes. Consequently, the coverage of collective agreements among unskilled labor migrants is particularly important to explore. The sectors chosen for our study - restaurants and cleaning - are 
also characterized by rates of unionization far below the Swedish average, which may further restrict the prospects of trade unions to control the employment conditions of labor migrants.

Our second hypothesis for explaining why so many labor migrants from non-EU/ EEA countries were recruited into surplus occupations is that, contrary to the expectations in the government bill mentioned above, employers with non-EU/EEA background may have preferred using transnational networks to recruit nondomestic workers. In the Swedish restaurant sector, approximately every second employer was born abroad. An indicator of the importance of social networks is the migrants' statements concerning how they had obtained knowledge of job vacancies.

Our third hypothesis is that the demand for work permits from different kinds of track changers accounts for a significant inflow of labor migrants from third countries. The 2008 legislation made it possible to 'change track' from asylum seeker to labor migrant after the application for asylum was rejected, provided that the migrant had worked for at least six months. Taking into account its relatively small size, Sweden has received more asylum seekers than almost all other EU countries. Former students can also apply to change their track to labor migrants.

Fourthly, it is possible that some third-country labor migrants in the restaurant and cleaning sectors were recruited to shortage occupations where skilled cooks may be the most prominent example.

These four hypotheses are not mutually exclusive. For example, the vulnerability of labor migrants might be reinforced when combined with a high demand for work permits from former asylum seekers, as these persons might be prepared to accept bad working conditions to get a chance to remain in or return to Sweden. Employers of the same nationality as the labor migrant may not only function as support in a foreign country but may also increase the vulnerability of the migrant.

The large number of work permits issued in the Stockholm restaurant and cleaning sectors in 2012 caused us to choose this city for closer examination. Stockholm is of additional interest owing to its lower union density and coverage of collective agreements than in the rest of Sweden. However, the rate of unemployment is below the Swedish average.

To test our hypotheses, we carried out a detailed primary study of all new work permits granted in 2012 in the selected sectors in Stockholm municipality. Using the almost 500 labor migrant dossiers in the archives of the Swedish Migration Agency, business registers, and trade union registers of collective agreements, we constructed a database to record the migrants, the companies which had recruited them, the employment conditions offered, and the opinions of trade unions.

Among other things, we investigated the size and character of the recruiting firms, the degree to which they had signed collective agreements, trade union approval rates of the labor permits, the degree to which migrants and employers have links to the same country of origin, and whether the labor migrants were former asylum seekers who had changed track. Finally, we examined the occupations specified in the work permits.

As is shown below, the number of new labor permits granted to third-country migrants in the restaurant and cleaning sectors increased up to and including 2011 and began to decline in 2012. Tentative explanations for this trend and for the increase in 2017 are presented. The article begins with an overview and analysis of the labor 
immigration trends in Sweden between 2009 and 2017. We then present the results of our primary study. Finally, we make a comprehensive analysis of the findings.

\section{THE INCREASE AND DECLINE IN WORK PERMITS - AND NEW INCREASE}

The number of new work permits in the restaurant and cleaning industries more than doubled during the years immediately following the labor immigration reform (Table 1). Thereafter, the upward trend was broken, decreasing from about 2900 new permits in 2011 to about 1100 in 2016. In Stockholm, the decline was even sharper. One possible explanation is that in January 2012 and August 2014, the Migration Agency introduced stricter controls due to the discovery of several cases of labor migrant exploitation.

In 2012, the number of granted permits was still quite large, but this can be explained by backlogs in case management; there was a lag before the stricter rules had

Table I Granted new work permits in some occupational groups in Sweden, Stockholm county, and Stockholm municipality, 2009-2017

\begin{tabular}{|c|c|c|c|c|c|c|c|c|c|c|c|}
\hline & 2009 & 2010 & 2011 & 2012 & 2013 & 2014 & 2015 & 2016 & Total & $\begin{array}{c}\text { Change } \\
2011-2016\end{array}$ & 2017 \\
\hline \multicolumn{12}{|l|}{ Sweden } \\
\hline $\begin{array}{l}\text { Food preparation as- } \\
\text { sistants etc. }\end{array}$ & 257 & 546 & 800 & 570 & 470 & 553 & 581 & 400 & 4177 & $-400(-50 \%)$ & 782 \\
\hline Cooks etc. & 769 & 1048 & 1327 & 862 & 831 & 865 & 740 & 537 & 6979 & $-790(-60 \%)$ & 849 \\
\hline $\begin{array}{l}\text { Restaurant employees } \\
\text { total }\end{array}$ & 1026 & 1594 & 2127 & 1432 & 1301 & 1418 & 1321 & 937 & 11,156 & $-1190(-56 \%)$ & 1631 \\
\hline Cleaners & 295 & 488 & 799 & 554 & 397 & 263 & 219 & 197 & 3302 & $-602(-75 \%)$ & 515 \\
\hline Total & 1321 & 2082 & 2926 & 1986 & 1698 & 1681 & 1540 & 1134 & 14,348 & $-1792(-6 \mid \%)$ & 2146 \\
\hline \multicolumn{12}{|l|}{ Stockholm County } \\
\hline $\begin{array}{l}\text { Food preparation as- } \\
\text { sistants etc. }\end{array}$ & 161 & 325 & 439 & 265 & 221 & 226 & 260 & 168 & 2065 & $-27 \mid(-62 \%)$ & 403 \\
\hline Cooks etc. & 280 & 366 & 515 & 307 & 243 & 230 & 206 & 172 & 2319 & $-343(-67 \%)$ & 283 \\
\hline $\begin{array}{l}\text { Restaurant employees } \\
\text { total }\end{array}$ & 441 & 691 & 954 & 572 & 464 & 456 & 466 & 340 & 4384 & $-614(-64 \%)$ & 686 \\
\hline Cleaners & 220 & 406 & 675 & 420 & 269 & 161 & $|4|$ & 132 & 2424 & $-543(-80 \%)$ & 379 \\
\hline Total & 661 & 1097 & 1629 & 992 & 733 & 617 & 607 & 472 & 6808 & $-1 \mid 57(-7 \mid \%)$ & 1065 \\
\hline \multicolumn{12}{|l|}{ Stockholm Municipality } \\
\hline $\begin{array}{l}\text { Food preparation as- } \\
\text { sistants etc. }\end{array}$ & 108 & 200 & 272 & 174 & 169 & 128 & 184 & 100 & 1335 & $-192(-7 \mid \%)$ & 255 \\
\hline Cooks etc. & 193 & 232 & 307 & 174 & 158 & 143 & 142 & 115 & 1464 & $-192(-63 \%)$ & 194 \\
\hline $\begin{array}{l}\text { Restaurant employees } \\
\text { total }\end{array}$ & 301 & 432 & 579 & 348 & 327 & 271 & 326 & 215 & 2799 & $-364(-63 \%)$ & 449 \\
\hline Cleaners & 118 & $|8|$ & 322 & $|8|$ & 96 & 91 & 75 & 61 & 1125 & $-26 \mid(-8 \mid \%)$ & 214 \\
\hline Total & 419 & 613 & 901 & 529 & 423 & 362 & 401 & 276 & 3924 & $-625(-69 \%)$ & 663 \\
\hline
\end{tabular}

Source: Swedish Migration Agency. 
an impact. Most work permits granted that year in Stockholm were based on applications submitted in 2011 and therefore were not covered by the more stringent rules. Out of about 2000 new work permits in the restaurant and cleaning sectors, half were issued in Stockholm County and one in four in the city of Stockholm.

The financial crisis might also have contributed to the decline in the number of granted work permits, but employment statistics contradict this hypothesis. Unlike the situation in Sweden's export industry, the number of employees in restaurants and hotels continued to increase. The cleaning sector was affected very little by the economic crisis.

Another contributory factor appears to be that employers found new means to employ third-country migrants already residing in the country at very low costs. There are several forms of wage subsidies available for employers who hire unemployed and newly arrived immigrants. According to Refslund and Thörnquist (2016), the main employer strategy to deal with the fierce competition in the restaurant and cleaning sectors has been to employ domestic workers - including previous immigrants - subsidized through the Public Employment Service. As up to $80 \%$ of the wage is paid for by the state and wage costs constitute the lion's share of the total costs for many firms, these subsidies create a powerful incentive for employers to employ subsidized labor. In the hotel and restaurant industry, the number of granted wage subsidies increased by almost 40\% between 2011 and 2015.

Despite the strong decline after 2011 in new work permits granted to cleaners, food preparation assistants, and cooks, both the number and the share of workers born abroad (and who come mostly from non-EU countries) has continued to increase in these occupations (Table 2). It is likely that some were asylum seekers with jobs pending the decision of the Migration Agency as well as refugees and others who had already been granted permanent residence permits.

Labor immigration from non-EU countries after 2011 decreased faster in cleaning than in the restaurant sector. Only a few hundred cleaners received new work permits in 2015 and 2016 (Table 1). However, the share of cleaners born outside EU in the labor force has increased markedly, to $40 \%$ in 2015 , that is, three quarters of all cleaners born abroad (Table 2). Between 2011 and 2015, persons born outside EU accounted for almost the entire increase of foreign-born cleaners. In contrast to Denmark, Sweden's inflow of EU labor migrants in cleaning has been comparatively low (Refslund \& Thörnquist, 2016:67).

Sweden abstained from transitional rules in the 2004 and 2007 EU enlargements. A possible explanation for the limited inflow of EU cleaning workers is that many employers preferred non-EU labor migrants due to their vulnerable position caused by the required link to a specific employer and occupation, while EU citizens can move freely between employers, occupations, and countries. In addition to the combination of openness and the creation of a vulnerable category of third-country labor migrants, Sweden receives more refugees per capita than any other Nordic country. This in turn is putting pressure on third-country nationals whose asylum applications have been rejected to change track from refugee to labor migrant. In addition, because of the massive refugee inflow, there are many third-country nationals available for employment in Sweden. It should be observed that work permits are often not required for asylum seekers while their application is pending, or for guest students and individuals with a permanent residence permit (Calleman \& Herzfeld Olsson, 2015). 
Table 2 Employees born abroad by selected occupations in Sweden, 16-64 years: 2009-20I5

\begin{tabular}{|c|c|c|c|c|c|}
\hline & \multirow{2}{*}{$\begin{array}{c}\text { All } \\
\text { employees }\end{array}$} & \multicolumn{2}{|c|}{ Born abroad } & \multicolumn{2}{|c|}{ Share born abroad } \\
\hline & & All & Third countries & All & Third countries \\
\hline \multicolumn{6}{|l|}{2009} \\
\hline Hotel and office cleaners etc. & 66,100 & 28,200 & 21,500 & $43 \%$ & $33 \%$ \\
\hline Food preparation assistants etc. & 57,600 & 14,700 & 12,000 & $26 \%$ & $21 \%$ \\
\hline Cooks & 32,000 & 7300 & 5000 & $23 \%$ & $16 \%$ \\
\hline Total 2009 & 155,700 & 50,200 & 38,500 & $32 \%$ & $25 \%$ \\
\hline \multicolumn{6}{|l|}{2011} \\
\hline Hotel and office cleaners etc. & 69,800 & 32,100 & 24,600 & $46 \%$ & $35 \%$ \\
\hline Food preparation assistants & 61,600 & 17,800 & 15,000 & $29 \%$ & $24 \%$ \\
\hline Cooks & 35,300 & 9500 & 7300 & $27 \%$ & $21 \%$ \\
\hline Total $201 \mathrm{I}$ & 166,700 & 59,400 & 46,900 & $36 \%$ & $28 \%$ \\
\hline \multicolumn{6}{|l|}{2013} \\
\hline Hotel and office cleaners etc. & 71,100 & 34,700 & 26,700 & $49 \%$ & $38 \%$ \\
\hline Food preparation assistants & 67,700 & 20,600 & 17,600 & $30 \%$ & $26 \%$ \\
\hline Cooks & 37,200 & 10,800 & 8500 & $29 \%$ & $23 \%$ \\
\hline Total 2013 & 176,000 & 66,100 & 52,800 & $38 \%$ & $30 \%$ \\
\hline \multicolumn{6}{|l|}{$2015 *$} \\
\hline Cleaners & 74,500 & 39,300 & 29,900 & $53 \%$ & $40 \%$ \\
\hline Food preparation assistants etc. & 67,700 & 22,300 & 19,300 & $33 \%$ & $29 \%$ \\
\hline Pizza bakers, street kitchen assistants, etc. & 2700 & 1900 & 1800 & $70 \%$ & $67 \%$ \\
\hline Cooks & 39,100 & 11,900 & 9500 & $30 \%$ & $24 \%$ \\
\hline Total 2015 & 184,000 & 75,400 & 60,500 & $41 \%$ & $33 \%$ \\
\hline
\end{tabular}

*: Not quite comparable with previous years due to changed occupational classification.

Source: Swedish Occupational Register.

Due to the large inflow of refugees to Sweden in 2015 - 163,000 persons - resulting in extremely lengthy processing of asylum applications, the Migration Agency had to give low priority to work permit applications, especially in sectors subject to reinforced controls such as the restaurant and cleaning industries. That was a major reason why relatively few work permits were granted in 2015 and 2016 in these industries. The processing of work permit applications was expedited considerably in 2017 and the number of granted new work permits almost doubled (Table 1). In 2017 after receiving criticism, the Migration Agency eased its control routines with a view to eliminate rejections based on minor employer mistakes. In the aftermath of the 2015 wave of refugees, the number of track changers from asylum to labor migrants increased fivefold between 2016 and 2017 (refers to the whole labor market).

In 2014, in Finland, $23 \%$ of all cleaners were foreign-born, followed by $18 \%$ of food preparation assistants (Ollus, 2016:27). These percentages are far below the Swedish rates (Table 2). Ollus (2013:31) argues that the Finnish demand for foreign cleaners can be explained by the fact that the labor force is 'divided into largely unavailable Finnish workers versus available migrant workers’. Many native Finns avoid cleaning jobs due to unattractive working hours (and tasks) and uneven demand on labor. Although 
Swedish office cleaning is mainly carried out during business hours (Refslund \& Thörnquist, 2016:67), the share of foreign-born cleaners is considerably higher than in Finland. In contrast to Sweden, $40 \%$ of all workers in Danish 'general cleaning' are from EU11, that is, from Eastern and Central Europe.

\section{TRACK CHANGERS VERSUS PURE LABOR IMMIGRANTS}

In contrast to berry-pickers, hardly any labor migrants in the restaurant and cleaning sectors are seasonal workers. Most of them appear to stay for the entire two-year period during which the work permit is usually valid. If the permit is prolonged for another two years, the migrant can obtain a permanent residence permit after four years of work. This seems to be a strong incentive for third-country citizens to work in Sweden. Furthermore, labor migrants are entitled to be accompanied by their family members, who have the right to obtain work permits (Emilsson, 2016:9).

Individuals whose asylum applications have been rejected can change tracks and become labor migrants and thus remain in the country. Normally, work permit applications must be submitted from abroad, but this is not applicable to former asylum seekers who reside in Sweden and who have worked for at least six months under wages and employment conditions that are in line with Swedish collective agreements (Calleman, 2015). Sweden is one of the few countries where asylum seekers have the right to work pending the asylum decision. It is also stipulated by law that the rejection of the asylum application must have been legally validated, and the application for a labor permit submitted within a two-week period after the rejection. By 'changing track' to that of labor migrants, asylum seekers can avoid expulsion.

In our study of new work permits granted in Stockholm in 2012, we found that a large number of asylum seekers or former asylum seekers did not fulfil the formal requirements for changing track to labor migrants. Nevertheless, they had been granted work permits. For example, even though the wage was too low or the work period shorter than six months, it turned out that they were able to change their track to become labor migrants. We classified such track changes from asylum seekers to labor migrants as informal track changes. Those who changed track in this way tended to be individuals who had resided in Sweden for a long time, and who had a long history of rejected asylum applications, appeals, and expulsion orders. In these cases, the application for a work permit must be submitted from abroad.

There are several varieties of informal track change. One variety makes it possible to travel safely to Sweden to seek asylum there. In such cases, the work permit precedes the formal application for asylum. We classify this practice as an informal change of track. These individuals focus initially on seeking asylum and the work permit is only a means to come to Sweden and seek asylum from inside the country. This variety can be described in terms of double changes of tracks, for example: (1) asylum application pursued but not possible to make from Syria, (2) work permit application possible from Syria and other countries, and (3) application for asylum after arrival to Sweden. It would have been misleading to classify these persons as 'pure' labor migrants.

Another type of informal track change is from residence permit based on a family connection (typically through marriage to a Swedish citizen) to one based on work. In this case, after a divorce, a work permit offers an opportunity to remain in Sweden. 
In contrast to track change from family connection to work, former students who are granted work permits by the Migration Agency are classified as one of two formal kinds of track changers. The Migration Agency classifies work permits issued to third-country citizens into three decision-making categories:

- 'Employee';

- 'Employee, former asylum seeker', labelled by the authors as a formal track changer from asylum seeker to labor immigrant;

- 'Employee, former student', labelled by the authors as a formal track changer from student to labor immigrant.

We label the two latter categories as formal track changers because the Migration Agency applies special rules for these, including that the application for work permit must not be made from abroad. Among the work permits granted in the category 'employee', we make a distinction between what we call 'pure' labor immigrants and the two types of informal track changers described above. Therefore, the category 'employee' can be divided into three subgroups:

- Pure labor immigrants;

- Informal track changers from asylum seekers to labor immigrants;

- Informal track changers from family connection persons to labor immigrants.

The two types of each formal and informal track changers together exceed $40 \%$ of all labor migrants granted new work permits 2012 in the restaurant and cleaning sectors in Stockholm (Table 3). Consequently, less than $60 \%$ were 'pure' labor immigrants. Out of the $30 \%$ that changed track from asylum seeker to labor migrant, only one-third of them $(10 \%)$ were formal track changers, while twice as many $(20 \%)$ consisted of informal track changers.

The various types of track changers created a strong demand for new work permits from third-country citizens who already resided in Sweden or had previously lived there for several years.

We found considerable differences in migration backgrounds when comparing occupations in the restaurant and cleaning sectors: $77 \%$ of the cooks and $85 \%$ of those that we label specialty cooks were 'pure labor migrants' in the sense that they had no history of track change (Tables 3 and 4). Specialty cooks are those with culinary skills, for example, sushi, Chinese food, and Indian food.

The high share of pure labor migrants among cooks prompted us to ask whether this was related to skilled cooks usually being considered as belonging to a shortage occupation. While only one quarter of all cooks changed track, half of all cleaners and food preparation assistants did so. However, there were considerable differences between the specialty cooks (making up the large majority of cooks) and other cooks. Despite the overrepresentation of pure labor migrants among cooks, and the status of cook as a relatively skilled occupation, other studies suggest that the cook occupation was not suffering a labor shortage in Sweden: this is explained below.

In sum, there are two major types of third-country labor immigrants. The first type changes tracks to become a labor migrant and is already residing or has resided in Sweden as an asylum seeker, student, or through a relationship with a Swedish citizen. 
Table 3 Granted new work permits by occupation and category in Stockholm 2012

\begin{tabular}{|c|c|c|c|c|c|c|c|}
\hline Occupational group & $\begin{array}{l}\text { Pure } \\
\text { work } \\
\text { permit }\end{array}$ & $\begin{array}{c}\text { Formal track } \\
\text { change from } \\
\text { asylum }\end{array}$ & $\begin{array}{l}\text { k Informal } \\
\text { n track change } \\
\text { from asylum }\end{array}$ & $\begin{array}{l}\text { Track change } \\
\text { from family } \\
\text { connection }\end{array}$ & $\begin{array}{c}\text { Track } \\
\text { change from } \\
\text { studies }\end{array}$ & Total - & $\begin{array}{l}\text { - of which } \\
\text { track } \\
\text { changers }\end{array}$ \\
\hline $\begin{array}{l}\text { Food preparation } \\
\text { assistants }\end{array}$ & $\begin{array}{c}79 \\
(47 \%)\end{array}$ & $\begin{array}{l}18 \\
(11 \%)\end{array}$ & $\begin{array}{c}38 \\
(23 \%)\end{array}$ & $\begin{array}{c}2 \\
(1 \%)\end{array}$ & $\begin{array}{c}30 \\
(18 \%)\end{array}$ & $\begin{array}{c}167 \\
(100 \%)\end{array}$ & $\begin{array}{c}88 \\
(53 \%)\end{array}$ \\
\hline Specialty cooks* & $\begin{array}{c}98 \\
(85 \%)\end{array}$ & $\begin{array}{c}1 \\
(1 \%)\end{array}$ & $\begin{array}{l}13 \\
(11 \%)\end{array}$ & $\begin{array}{l}1 \\
(1 \%)\end{array}$ & $\begin{array}{c}3 \\
(3 \%)\end{array}$ & $\begin{array}{l}116 \\
(100 \%)\end{array}$ & $\begin{array}{l}18 \\
(15 \%)\end{array}$ \\
\hline Other cooks & $\begin{array}{c}20 \\
(53 \%)\end{array}$ & $\begin{array}{c}2 \\
(5 \%)\end{array}$ & $\begin{array}{c}11 \\
(29 \%)\end{array}$ & $\begin{array}{c}2 \\
(5 \%)\end{array}$ & $\begin{array}{c}3 \\
(8 \%)\end{array}$ & $\begin{array}{c}38 \\
(100 \%)\end{array}$ & $\begin{array}{c}18 \\
(47 \%)\end{array}$ \\
\hline Total cooks & $\begin{array}{l}118 \\
(77 \%)\end{array}$ & $\begin{array}{c}3 \\
(2 \%)\end{array}$ & $\begin{array}{c}24 \\
(16 \%)\end{array}$ & $\begin{array}{c}3 \\
(2 \%)\end{array}$ & $\begin{array}{c}6 \\
(4 \%)\end{array}$ & $\begin{array}{c}154 \\
(100 \%)\end{array}$ & $\begin{array}{c}36 \\
(23 \%)\end{array}$ \\
\hline Hotel cleaners & $\begin{array}{c}3 \\
(20 \%)\end{array}$ & $\begin{array}{c}5 \\
(28 \%)\end{array}$ & $\begin{array}{c}4 \\
(22 \%)\end{array}$ & $\begin{array}{c}2 \\
(1 \mid \%)\end{array}$ & $\begin{array}{c}4 \\
(22 \%)\end{array}$ & $\begin{array}{c}18 \\
(100 \%)\end{array}$ & $\begin{array}{c}15 \\
(80 \%)\end{array}$ \\
\hline Other cleaners & $\begin{array}{c}79 \\
(53 \%)\end{array}$ & $\begin{array}{c}20 \\
(13 \%)\end{array}$ & $\begin{array}{c}32 \\
(22 \%)\end{array}$ & $\begin{array}{c}7 \\
(5 \%)\end{array}$ & $\begin{array}{c}11 \\
(7 \%)\end{array}$ & $\begin{array}{l}149 \\
(100 \%)\end{array}$ & $\begin{array}{c}70 \\
(47 \%)\end{array}$ \\
\hline Total cleaners & $\begin{array}{c}82 \\
(49 \%)\end{array}$ & $\begin{array}{c}25 \\
(15 \%)\end{array}$ & $\begin{array}{c}36 \\
(22 \%)\end{array}$ & $\begin{array}{c}9 \\
(5 \%)\end{array}$ & $\begin{array}{c}15 \\
(9 \%)\end{array}$ & $\begin{array}{l}167 \\
(100 \%)\end{array}$ & $\begin{array}{c}85 \\
(51 \%)\end{array}$ \\
\hline Supervisors*** & $\begin{array}{c}2 \\
(40 \%)\end{array}$ & $\begin{array}{c}2 \\
(40 \%)\end{array}$ & $\begin{array}{c}1 \\
(20 \%)\end{array}$ & $\begin{array}{c}0 \\
(0 \%)\end{array}$ & $\begin{array}{c}0 \\
(0 \%)\end{array}$ & $\begin{array}{c}5 \\
(100 \%)\end{array}$ & $\begin{array}{c}3 \\
(60 \%)\end{array}$ \\
\hline All occupations & $\begin{array}{l}281 \\
(57 \%)\end{array}$ & $\begin{array}{c}48 \\
(10 \%)\end{array}$ & $\begin{array}{c}99 \\
(20 \%)\end{array}$ & $\begin{array}{c}14 \\
(3 \%)\end{array}$ & $\begin{array}{c}51 \\
(10 \%)\end{array}$ & $\begin{array}{c}493 \\
(100 \%)\end{array}$ & $\begin{array}{c}212 \\
(43 \%)\end{array}$ \\
\hline All & $57 \%$ & \multicolumn{4}{|c|}{ 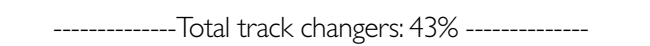 } & $100 \%$ & \\
\hline
\end{tabular}

*: Including chefs. **: In cleaning and restaurant sectors.

Source: project database.

Table 4 Share of 'pure' labor migrants and 'track changers', respectively, in Stockholm 2012

\begin{tabular}{lccc}
\hline Occupation & 'Pure' labor migrants & Track changers & Total \\
\hline Cooks, of which & $77 \%(118)$ & $23 \%(36)$ & $100 \%(154)$ \\
- specialty cooks & $85 \%(98)$ & $15 \%(18)$ & $100 \%(116)$ \\
- other cooks & $53 \%(20)$ & $47 \%(18)$ & $100 \%(38)$ \\
Food preparation assistants & $47 \%(79)$ & $53 \%(88)$ & $100 \%(167)$ \\
Cleaners & $49 \%(82)$ & $51 \%(85)$ & $100 \%(167)$ \\
Supervisors & $(2)$ & $(3)$ & $100 \%(5)$ \\
All occupations & $57 \%(28 \mathrm{I})$ & $43 \%(212 \mathrm{st})$ & $100 \%(493)$ \\
\hline
\end{tabular}

Remark. Number of labor migrants within parenthesis.

Source: project database.

By applying for a work permit, this individual hopes to remain in or return to Sweden. A work permit can also be a way to enter Sweden in order to seek asylum. In the Stockholm restaurant and cleaning sectors, migrants who had changed tracks to the labor immigrant track made up more than $40 \%$ of the new work permits holders in 2012 . The share of track changers rises to over $50 \%$ in the unskilled occupations of food preparation assistant and cleaner. Conversely, among cooks, track changers accounted for just over $20 \%$, and among specialty cooks, this share was just $15 \%$. 


\section{COUNTRIES OF ORIGIN: MOST FROM ASIA}

Two-thirds of the 493 labor migrants in our study came from Asia (excluding former Soviet republics). Somewhat surprisingly, the largest group of migrants came from Mongolia, followed closely by China and Bangladesh (Table 5).

The strong concentration of labor migrants to a rather small number of countries suggests that the migrant flows are based on social networks.

When we combined citizenship with occupation (Table 5), we found that 61 cooks came from China, 23 from Bangladesh, and 16 from Mongolia. Many of food preparation assistants were from Bangladesh, Syria, Egypt, and Mongolia. Among the cleaners, many were from Mongolia. The restaurant personnel from China - almost all cooks consists almost entirely of pure labor immigrants. Among the Syrians, track changers dominate. The labor migrants from Mongolia and Bangladesh also have a high proportion of track changers, with all of the former from asylum to work, and most of the latter from studies to work. Pelling (2015) shows that for many Iraqis, a work permit provides an alternative to seeking asylum.

The labor migration patterns found in Stockholm deviate considerably from those characterizing Sweden as a whole (Table 6). At the national level, Mongolians did not top the list in 2012, but comprised the fifth largest group. For the entire period 20092017, Chinese nationals were at the top of the list followed by Turks. In the third place, we find Syria, and in the fourth place Iraq.

\section{ETHNIC/NATIONALITY LINK BETWEEN EMPLOYER AND LABOR MIGRANT}

We also investigated how the migrants were recruited and how they learned about job vacancies, as these factors could influence the relationship between employer and employee. Of those who answered the question in the application document about how they acquired knowledge of the job, three out of four mentioned personal contacts

Table 5 Occupation by citizenship and type of labor migrants in Stockholm 2012

\begin{tabular}{lcccccccc}
\hline & Mongolia & China & Bangladesh & Syria & Egypt & Turkey & Iraq & Iran \\
\hline Total number, of which & 63 & 62 & 59 & 43 & 32 & 24 & 21 & 18 \\
- cooks, of which & 16 & 61 & 23 & 10 & 5 & 9 & 2 & 9 \\
'specialty cooks' & 11 & 60 & 20 & 5 & 1 & 3 & 0 & 7 \\
- food preparation assistants & 17 & 1 & 29 & 24 & 23 & 13 & 7 & 5 \\
- cleaners & 29 & 0 & 7 & 9 & 3 & 2 & 12 & 4 \\
Total food preparation & 46 & 1 & 36 & 33 & 26 & 15 & 19 & 9 \\
assistants + cleaners & & & & & & & & \\
Supervisors & 1 & 0 & 0 & 0 & 1 & 0 & 0 & 0 \\
Share of 'pure' labor migrants & $41 \%$ & $98 \%$ & $39 \%$ & $19 \%$ & $84 \%$ & $83 \%$ & $81 \%$ & $78 \%$ \\
Track changers & $59 \%$ & $2 \%$ & $61 \%$ & $81 \%$ & $16 \%$ & $17 \%$ & $19 \%$ & $22 \%$ \\
\hline
\end{tabular}

Remark. Refers to new work permits in the restaurant and cleaning sectors.

Source: project database. 
Table 6 The 10 most common countries of origin, 2009-2017 (new work permits, Sweden)

\begin{tabular}{|c|c|c|c|c|c|}
\hline & 2009 & 2010 & 2011 & $2012 *$ & 2013 \\
\hline । & China 295 & Turkey 434 & Turkey 392 & China 244 (62) & Syria 222 \\
\hline 2 & Turkey 187 & China 400 & China 30I & Turkey 240 (24) & China 218 \\
\hline 3 & Thailand I 30 & Iraq 145 & Syria 223 & Syria I76 (43) & Turkey 162 \\
\hline 4 & Bangladesh 100 & Thailand I43 & Iraq 196 & Iraq I $48(2 \mid)$ & Thailand I59 \\
\hline 5 & Iraq 60 & Syrial42 & Mongolia 172 & Mongolia I38 (63) & Bangladesh 134 \\
\hline 6 & Pakistan 58 & Mongolia |30 & Egypt 145 & Bangladesh 1 I 8 (59) & Mongolia 108 \\
\hline 7 & Mongolia 43 & Bangladesh 101 & Bangladesh 124 & Egypt 85 (32) & Iraq 100 \\
\hline 8 & India 42 & $\operatorname{Iran} 70$ & Thailand II0 & Pakistan 8I (9) & Vietnam 64 \\
\hline 9 & Iran 40 & Vietnam 70 & Vietnam 97 & Thailand 79 (4) & $\operatorname{Iran} 59$ \\
\hline \multirow[t]{2}{*}{10} & Syria 32 & Egypt 69 & Pakistan 96 & Iran $77($ ( 8) & Pakistan 55 \\
\hline & 2014 & 2015 & 2016 & 2017 & 2009-2017 \\
\hline l & China 25I & Turkey 235 & China 186 & Turkey 30I & China 2377 \\
\hline 2 & Syria 235 & China $|8|$ & Thailand 109 & China 245 & Turkey 2283 \\
\hline 3 & Turkey 229 & Iraq 178 & Turkey 103 & Mongolia 209 & Syria 1248 \\
\hline 4 & Thailand 117 & Syria 148 & Iraq 100 & Iraq I44 & Iraq 1160 \\
\hline 5 & Bangladesh 101 & Thailand $|3|$ & Vietnam 84 & Thailand 139 & Thailand I। 17 \\
\hline 6 & Iraq 89 & Egypt 86 & Bangladesh 67 & Vietnam 136 & Mongolia 968 \\
\hline 7 & Vietnam 76 & Bangladesh 82 & Mongolia 53 & Bangladesh 133 & Bangladesh 960 \\
\hline 8 & Mongolia 55 & Vietnam 75 & Egypt 39 & Egypt 105 & Egypt 635 \\
\hline 9 & Egypt 49 & Mongolia 60 & India 33 & Pakistan 7I & Pakistan 532 \\
\hline 10 & Iran 44 & Pakistan 43 & Syria 28 & India 60 & Iran 475 \\
\hline
\end{tabular}

*: Within parenthesis refers to Stockholm 2012.

Remark. Number of labor migrants in the restaurant and cleaning sectors.

Source: Swedish Migration Agency.

(friends, relatives, employers), while one in four had acquired information through the Public Employment Service or an advertisement. A few also mentioned recruitment agencies in their home country. According to Vogiazides and Hedberg (2013:193), such agencies are used fairly often by Chinese restaurant owners in Sweden.

To get a better understanding of the importance of social networks, we investigated whether the employer or the contact person in the company was of the same nationality as the migrant. The migrant's citizenship was always specified in the documents, while we defined the employers' national backgrounds mainly on the basis of their names (therefore our data are somewhat uncertain).

There are large variations between different migration groups regarding the frequency of nationality links between employer and labor migrant. For all Chinese migrants except one, we found such a link. For the Bangladeshis, the share was over $50 \%$ and almost $20 \%$ for Mongols.

It appears that mainly smaller firms employ migrants through national or ethnic networks. Three quarters of the migrants in firms with one to four employees seem to be of the same nationality as their employer. This proportion drops gradually to about every second migrant in firms with 20-49 employees. Almost all migrants in companies with more than 100 employees lacked a nationality connection to their employer. 
Overall, slightly more than half of all labor migrants appeared to have a nationality link to their employer.

Among the 'pure' labor migrants who came directly to Sweden on the basis of their work permit, more than two-thirds had a nationality connection to the employer, indicating that they had come in contact with the employer through a transnational network. Of those who formally changed tracks from asylum seekers to labor migrants, far fewer seemed to have a nationality link to the employer compared to informal track changers.

\section{EVERY SECOND LABOR MIGRANT WITHOUT A COLLECTIVE AGREEMENT}

We also sought to map some of the main characteristics of the firms recruiting migrants from third countries. Almost $85 \%$ of the migrants, and almost all cooks, worked in small companies, which in Swedish official statistics are those with fewer than 50 employees. About $60 \%$ of the labor migrants worked for employers with fewer than 10 employees.

Of the 350 companies surveyed, $42 \%$ had signed some form of collective agreement. More than one in four belonged to an employers' organization and were therefore covered by sectoral collective agreements. Of the 215 companies with up to nine employees, only one-third had a collective agreement. Most of these were substitute agreements, that is, directly between the company and the union. Conversely, of the 32 firms with at least 50 employees, $91 \%$ had collective agreements, of which almost all were national agreements. These variations between companies of different sizes probably correspond to what is applicable for the restaurant and cleaning sectors in general in Stockholm.

Every second labor migrant included in our study worked for employers without collective agreements. Among food preparation assistants, this share was higher (Table 7). In contrast, only $40 \%$ of the cleaners were employed in firms without collective agreements. Almost all hotel cleaners worked in firms with (sectoral) collective agreements. This might be explained by the fact that many hotels in Stockholm are rather large, and members of the Visita employers' association.

Table 7 Share of labor migrants with/without collective agreement by occupation

\begin{tabular}{lcc}
\hline Occupation & No collective agreement & Collective agreement \\
\hline $\begin{array}{l}\text { Food preparation assistants excluding } \\
\text { dishwashers }\end{array}$ & $59 \%$ & $41 \%$ \\
Dishwashers & $50 \%$ & $50 \%$ \\
Total food preparation assistants & $57 \%$ & $43 \%$ \\
including dishwashers & & \\
Cooks & $53 \%$ & $47 \%$ \\
Total restaurant sector & $55 \%$ & $45 \%$ \\
Hotel cleaners & $11 \%$ & $89 \%$ \\
Other cleaners & $45 \%$ & $55 \%$ \\
Total cleaners & $41 \%$ & $59 \%$ \\
Total & $51 \%$ & $49 \%$ \\
\hline
\end{tabular}

Source: project database. 
In 2012, almost $85 \%$ of all private sector employees in Sweden worked in companies covered by a collective agreement. There are no statistical data available on the average coverage rates in the Swedish restaurant and cleaning sectors, but they could be expected to be lower, especially in Stockholm. While about $85 \%$ of all private sector employees in Sweden are covered by collective agreements, only $35-40 \%$ of all companies with employees have signed collective agreements. The discrepancy can be explained by the fact that most companies are very small, and the large majority of the employees are found elsewhere. Nevertheless, the fact that every second labor migrant in our study did not have a collective agreement for their workplace is remarkable, because work permits require wages and other employment conditions equivalent to those stipulated in collective agreements.

Almost all the 250 labor migrants at workplaces without collective agreements were found in small companies (fewer than 50 employees) employing almost six out of ten migrants in our study. While over $90 \%$ of the labor migrants in the companies with at least 50 employees were covered by collective agreements, the coverage rate was just $40 \%$ in those with $1-49$ employees.

\section{The trade union assessments}

The Migration Agency must consult with a relevant trade union, and ask for its opinion about the wage and employment conditions offered in the application documents. Among the unions consulted were the Hotel and Restaurant Employees' Union, the Maintenance Employees' Union, and the Municipal Workers' Union.

The Migration Agency is not obliged to follow union recommendations and is not allowed to reject work permit applications only because there is no collective agreement in place. Approval for the permit requires only that the offered wage is not lower than the minimum level stipulated in the agreement, and that the employer provides the employee with sickness, injury, life, and occupational pension insurances. Since 2012, when more restrictive rules were introduced in the restaurant and cleaning sectors, the employer must submit payslips if the migrant already is or has been employed in Sweden. On the basis of annual accounting records, the Migration Agency investigates whether firms have the funds required to pay wages during the first three months. The stricter rules were applied before 2012 in cases of formal track changes from asylum seeker to labor migrant.

In half of the cases, the unions found that the offered employment conditions were consistent with the collective agreement. In approximately $40 \%$ of the cases, they deemed conditions to be worse, and for $7 \%$ of the cases, they declined to comment.

Where a collective agreement existed, the unions considered the work offers in nine out of ten cases as 'not worse' than what was stipulated in the collective agreement, while only one out of five work offers from employers without a collective agreement was considered to be in line with the agreement. If the unions select the option 'is worse', they are asked to specify what 'is worse'. In every third case, no reason was stated. No insurance or insufficient insurances was the most common reason $(41 \%)$ followed by wage rates below agreements levels $(10 \%)$ and the combination of low wages and or insufficient or nonexistent insurances $(7 \%)$.

When unions assessed the terms to be 'worse' than those stated in the collective agreement, in four cases out of ten, they used the phrasing 'there are no guarantees' that 
the employer provides a comprehensive insurance cover for the migrant (this percentage excludes union assessments not specifying what 'is worse'). This share increases to seven in ten with the addition of assessments specifying that insurances are missing or defective. That makes insufficient insurance coverage the single most commonly stated reason for judging the offered employment conditions to be worse than those in the collective agreement.

In the form for union opinion, there is space for 'further comments'. Above all, the Hotel and Restaurant Employees' Union often included their own statement of 'approves' or 'rejects'. In all 137 approvals issued by this union, the company had a collective agreement. In similar vein, $88 \%$ of the 185 rejections were motivated by 'lack of collective agreement'.

In any case, trade union comments did not seem to influence the Migration Agency's decision-making processes. The agency ignored the fact that in $40 \%$ of the granted permits, that the offered employment conditions were considered worse than those of collective agreements. There is reason to exclude the Maintenance Employees' Union with respect to the number of rejections, as it usually did not indicate rejection or approval of work permits. In its assessment of 322 granted work permits, the Hotel and Restaurant Employees' Union rejected $49 \%$ and approved 37\%. Nevertheless, the position of the Migration Agency should be viewed in the light of its assigned task: to assess whether the applications, in a formal sense, are in accordance with applicable legislation.

\section{CONCLUDING DISCUSSION}

In our study of new work permits granted in 2012 to third-country migrants in Stockholm's restaurant and cleaning sectors, we found considerable demand for work permits from individuals who 'changed tracks' from asylum seekers, as well as former students and others applying for work permits to remain in or return to Sweden. In total, $43 \%$ of the new work permits were issued to persons who were changing tracks. Most of these track changers were recruited into low-skilled occupations, while a significant portion of the 'pure' work permits were issued to cooks, and in particular 'specialty cooks'.

The recruitment of track changers was certainly facilitated by the fact that many of them were already residing in Sweden or had done so in the past. It is also reasonable to assume that track changers were keen to get a work permit to avoid having to leave the country. The many requirements to be met for a formal change of track from asylum seeker to labor migrant (Calleman, 2015) made an informal track change a realistic alternative for many individuals.

For those who already had been deported after lengthy processes of asylum applications and appeals, the work permit provided an opportunity to return to Sweden. For some refugees, getting a work permit was a much safer way of travelling to Sweden compared to making the journey via risky smuggling routes.

Together with the track changers in all occupations, the cooks in the category 'pure labor migrants' made up two-thirds of the new work permits. The cooks accounted for almost half of those recruited into the restaurant sector.

At first glance, this appeared to explain why so many work permits were issued in the restaurant and cleaning sectors. The demand for work permits from track changers 
combined with a demand for skilled cooks appeared to explain the vast majority of work permits issued in the restaurant and cleaning sectors.

Our hypothesis was that the recruitment of cooks from third countries occurred to satisfy the demand for employees in a shortage occupation. Furthermore, it seemed reasonable to assume that specialty cooks, of whom $85 \%$ were pure labor migrants, had specific skills in Chinese or South Asian cuisine.

However, it is questionable whether cooks really can be considered a shortage occupation. Emilsson et al. (2014:50) and Emilsson (2016:11) classified cooks as a surplus occupation because third-country migrants recruited as cooks often carried out unskilled work. Furthermore, statistics from Statistics Sweden and the Swedish Tax Agency showed that labor migrants from third countries who were recruited as cooks in 2009 had significantly lower incomes than 'helpers in restaurants' after two years (Emilsson et al., 2014:51, 54). Similarly, OECD found that the wages paid to thirdcountry labor migrants after the 2008 reform had entered into force were significantly lower compared to those paid to other employees (OECD, 2011:98).

A possible explanation for the discrepancies between stated and actual wage is that the employer and the migrant have reached an informal agreement to that effect. Axelsson et al. (2013) suggest that this may be the case for a large share of the specialty cooks, most of whom were recruited from China. Their study based on in-depth interviews with Chinese cooks showed that many of those recruited through relatives were not trained, and did not have relevant work experience before coming to Sweden. Wages varied significantly among the interviewees. The wage stated in the employment offer was typically about 18,000 SEK before tax, while the actual salary amounted to about 8000 after tax. The migrant and the employer agreed to this arrangement so that the Migration Agency would approve the work permit application. To fulfil the official requirements, the employer paid the tax corresponding to the wage stated in the job offer. Before the tightened control of the companies' tax payments introduced in August 2014, the Migration Agency noted that there was 'a widespread abuse of the regulatory framework for labor immigration' (Migration Agency, 2013).

According to Axelsson et al. (2013), many Chinese cooks were willing to accept a low wage to obtain a job in Sweden. Their actual working time was reported to be around 10-13 hours per day, six days a week. Cooks with permanent residence permit typically do not accept having to work more than five days a week. Once the Chinese workers had been granted permanent residence permits, owners of Chinese restaurants might have found it more attractive to recruit new cooks from China rather than retaining those who were being granted permanent residence permits.

Another method of wage suppression for cooks was found by the Hotel and Restaurant Employees' Union in its 2012 investigation of 64 restaurants with collective agreements and labor migrants. It was not uncommon that cooks were given another job title, such as food preparation assistant to justify a lower wage than that stipulated in the collective agreement (HRF, 2012).

In our study, two-thirds of the work permits were issued for food preparation assistants and cleaners, that is, jobs with limited qualification requirements and where the competition for jobs is often fierce. Consequently, most recruitment of workers from third countries to the restaurant and cleaning sectors did not serve to satisfy a demand for labor in shortage occupations. As was shown above, this is questionable even in the case of many cooks. 
In the light of the high unemployment in Stockholm's restaurant and cleaning sectors, the question is why so many migrants were recruited into low-skilled occupations. In 2011-2012, around 10\% of the members of the unemployment fund of the Hotel and Restaurant Employees' Union were registered as unemployed, and 23\% when part-time unemployed were included. In the Maintenance Employees' Fund, the corresponding rates were $7 \%$ and $17-18 \%$, respectively.

Considering the many unemployed workers available to recruit as cleaners and food preparation assistants in Stockholm and its immediate vicinity, the very frequent nationality links between employee and employer appears to be a likely explanation why so many third-country migrants were recruited. It is possible that employers of foreign origin wanted to help conationals get a job in Sweden, while at the same time that some of them - in practice but not in the migration documents - offered employment conditions which permanent residents were unwilling to accept. During this same period, many young Swedes preferred low-skilled restaurant jobs in Norway and Denmark that offered better pay.

Employers offering conditions below what is considered to be the 'normal' level are likely to experience a shortage of labor (LO, 2013:27). This hypothesis is supported by Andersson Joona and Wadensjö (2012) who found that recently arrived immigrants employed by conationals have significantly lower taxable incomes than others with comparable jobs. Furthermore, to a very large extent, immigrant entrepreneurs employ conationals who tend to remain in the 'ethnic enclave economy'; this is confirmed by Urban (2013). This tendency has contributed to the emergence of an ethnically segregated and segmented labor market. In our study, more than $60 \%$ of the employers appeared to have a nationality link to their third-country labor immigrant employees. It was most common in small companies.

In research on ethnic companies in USA and Latin America, Portes (2010) highlights the importance of informal agreements and strong social control based upon personal contacts, ethnicity, and vertical ties between employer and employee in contrast to horizontal, class-based solidarity. Under such circumstances, employees may be much less inclined to protest against poor work conditions and low wages. What Bauder calls a false loyalty to employers of the same ethnicity may prompt migrants to passively accept poor working conditions (Bauder, 2006:142, 154).

While a nationality/ethnic affinity between the migrant and the employer may afford a sense of security in a foreign country, it may also put the migrant in a vulnerable position. If the employer provides accommodation, as in the case of the interviewed Chinese cooks, another dimension of dependency is added. This is further accentuated by the scarcity of housing in Stockholm. In the restaurant sector, debt due to illegal fees paid to get an employment offer during the recruitment process is said to be common in both Sweden and Finland (Ollus \& Jokinen, 2013:69-77; Vogiazides \& Hedberg, 2013:194-198, 213).

The labor immigrants can be characterized as unfree workers in so far as the work permit is linked to a specific occupation and a specific employer. Free workers can change employer and occupation whenever they wish. The labor migrants do not even have the right to be unemployed for a longer period. Deportation will follow if the migrant fails to find a new job, and get a new work permit in the same occupation within a few months (after the first two years of work permit validity, however, the occupation must not be the same). One might say that the Swedish 2008 labor immigration legislation 
'constructs' unfree labor. This contrasts sharply with the employers' freedom to recruit workers from all over the world, provided that some, not legally binding, employment conditions are included in the employment offer document. According to the law, the employment conditions should be at least equivalent to those in collective agreements, but the very same law opens up for processes that threaten to put such conditions out of the running.

The combined freedom of employers and lack of freedom of migrants generates a very uneven balance of power, manifested in a precariat distinguished by both uncertainty and dependency on others. Under such circumstances, informal relations can strongly affect working and employment conditions, particularly as many labor migrants in our study were working in small companies where they had an ethnic/nationality link to the employer. The dependency is deepened by the linkage of the work permit to a particular employer. The employer can terminate the employment if the migrant expresses discontent with the working conditions or tries to negotiate for improved conditions (Bonfati, 2014:383). Migration researchers like Anderson and Ruhs (2012) argue that the absence of a permanent residence permit increases the pressure on migrants to accept working and employment conditions below the normal standard, especially in sectors with high unemployment such as the restaurant and cleaning sectors (see also Bauder, 2006:116).

Such processes of informalization are reinforced by the fact that the clear majority of third-country labor migrants are not members of trade unions (Vogiazides \& Hedberg, 2013:217-218) and that many are recruited to workplaces without collective agreements where the unions' prospects for inspecting the employment conditions are more or less nonexistent.

Some results from our study are as follows:

- The study revealed a high share of track changers (more than $40 \%$ ) among those granted new work permits in the restaurant and cleaning sectors in Stockholm. The most common variety was a change of track from asylum seeker to labor migrant as an alternative way to obtain a permanent residence permit. This conforms to our third hypothesis about why so many third-country nationals were recruited to the restaurant and cleaning sectors in Stockholm during 2012.

- In accordance with our second hypothesis, a large share of the labor migrants - more than one in two - appears to have a nationality/ethnic link to the employer. This is most common among the 'pure labor migrants' (two-thirds of them) and especially among Chinese cooks. In the smallest firms (one to four employees), three quarters of the labor migrants and their employer were conationals.

- Numerous circumstances, among them the design of the regulatory framework, put many labor migrants in a vulnerable position. Because the work permit links the migrant to a single employer in a particular occupation and expulsion will follow after a few months of unemployment if the migrant loses the job, very unequal power relations are created. Through the restrictions on the migrant which are inherent in the work permit, the legislation constructs employment relations which strongly resemble the conditions of unfree labor. On the other hand, the prospects of getting a permanent residence permit after four years of work certainly appear very attractive for both economic migrants and track changers from asylum. This combination of restrictions and prospects easily makes labor migrants from third countries subject to exploitation. Therefore, the absence of collective agreements and trade unions in the workplace will potentially have much more serious consequences for labor 
migrants from third countries than for other workers.

- Half of the labor migrants in our study were not covered by a collective agreement. In firms with one to four employees, this was the case for three quarters of the migrants. Only $35 \%$ worked in companies affiliated with an employer association and in firms with fewer than 10 employees just $15 \%$. Along with the fact that very few third-country migrants are trade union members, this reinforces the migrants' vulnerability, especially because the Swedish labor market model is distinguished by trade union access to workplaces based on high union density and high density of employers' associations. In addition, union density in the restaurant sector is by Swedish standards exceptionally low - less than $30 \%$ among blue-collar workers. The absence of mechanisms extending collective agreements to whole sectors contributes to many migrants' positon in workplaces outside the model. Furthermore, compared to Norway, for example, the powers and authority of Swedish government agencies to control workplace conditions are weak.

- Union rejection of work permit applications does not appear to influence the decisions of the Migration Agency. Behind the frequent union recommendations for rejection is a fear that the actual conditions in firms without collective agreements differ from the promised ones, especially because the latter are not legally binding and consequently no sanctions exist.

- Several indicators suggest, in line with our first hypothesis, that many employers take advantage of the vulnerable position of labor migrants, as described above. It is possible that employers seek both to help and at the same time exploit conationals, particularly in small firms without collective agreements. With respect to this situation, we have benefitted from studies carried out by other researchers, among them one study demonstrating that cooks in general are not recruited from third countries because this is a shortage occupation (cf our fourth hypothesis).

- In firms with fewer than 10 employees, three of four migrants were not covered by a collective agreement, irrespective of the existence or absence of a possible nationality link to the employer. However, among migrants with a possible nationality link to the employer, it was more than twice as common to be employed in firms with fewer than ten employees. Therefore, labor migrants employed by conationals were more often not covered by a collective agreement. This by itself puts these workers at a greater risk of exploitation.

- The sharp decline in the number of new work permits issued in the restaurant and cleaning sectors after the Migration Agency tightened controls - a move that prolonged processing times of work permit applications - indicates that many employers switched from recruiting third-country labor migrants to other channels. Employment subsidies may have become an attractive option for employers seeking to reduce wage costs. The large inflow of asylum seekers in 2015 caused the Migration Agency to give low priority to work permit applications in 2015 and 2016. Fewer refugees arriving to Sweden and more efficient routines for processing work permit applications are possible explanations for the high rate of granted work permits in 2017, which exceeded that of 2012. Another is the simultaneously rapid increase of track changers from asylum seekers to labor migrants. Finally, the booming Swedish economy in 2017 may have meant that a shortage demand for cooks could not be satisfied within the country. 


\section{Acknowledgment}

Financial support was granted by the Swedish Research Council for Health, Working Life and Welfare, also including an earlier version of this article in Arbetsmarknad \& Arbetsliv, spring 2017. URL: http://portal.research.lu.se/ws/files/22883855/Fr din Kjellberg Arbetskraftsmigration i 1 gl neyrken.pdf.

\section{References}

Åberg, R. (2012). Svensk arbetsmarknad mot polarisering efter millenieskiftet [Swedish labor market towards polarization since the Millenium], Arbetsmarknad \& Arbetsliv, 21 (4), 8-25, URL: http://kau.diva-portal.org/smash/get/diva2:915496/FULLTEXT01.pdf.

Anderson, B. and Ruhs, M. (2012). Reliance on Migrant Labour: Inevitability or Policy Choice?, Journal of Poverty and Social Justice, 20(1), 23-30, doi: https://doi. org/10.1332/175982712X626743.

Andersson Joona, P. and Wadensjö, E. (2012). Being Employed by a Co-national: A Cul-desac or a Short Cut to the Main Road of the Labour Market?, International Migration \& Integration, 13(19), 99-120, doi: http://dx.doi.org/10.1007/s12134-011-0195-3.

Axelsson L., Hedberg C., Malmberg, B. and Zhang, Q. (2013). Chinese Restaurant Workers in Sweden. Beijing: International Organization for Migration, URL: http://www.diva-portal.org/smash/get/diva2:691577/FULLTEXT01.pdf.

Bauder, H. (2006). Labor Movement. How Migration Regulates Labor Markets. Oxford: Oxford University Press.

Berg, L. and Spehar, A. (2013). Swimming against the tide: why Sweden supports increased labour mobility within and from outside the EU, Policy Studies 34(2), 142-161, doi: http://dx.doi.org/10.1080/01442872.2013.767585.

Bonfanti, S. (2014). New rules for Labour Immigration: Delving into the 2008 Swedish Reform of Labour Migration and Its Effects Migrants' Well-Being. International Migration \& Integration 15(3), 371-386, URL: https:/link.springer.com/content/pdf/10.1007\%2Fs12134-013-0290-8.pdf.

Boräng, F. and Cerna, L. (2017). Constrained Politics: Labour Market Actors, Political Parties and Swedish Immigration Policy, Government and Opposition, doi: http://dx.doi. org/10.1017/gov.2016.51.

Calleman, C. (2015). Byta spår. Ett nålsöga mellan asyl och arbete [Changing track. A needle between asylum and work]. In Calleman C. and Herzfeld Olsson P. (2015), 290-330.

Calleman, C. and Herzfeld Olsson, P. (eds.) (2015). Arbetskraft frän hela världen. Hur blev det med 2008 ars reform? [Labour from all over the world. What happened with the 2008 reform?]. Stockholm: Delmi.

Calleman, C. and Herzfeld Olsson, P. (2015). Inledning [Introduction]. In Calleman, C and Herzfeld Olsson P. (2015), 2-39.

Emilsson, H., Magnusson, K., Osanami Törngren, O. and Bevelander, P. (2014) The World's Most Open Country: Labour Migration to Sweden after the 2008 Law. Current Themes in IMER Research 15, Malmö University, URL: https://www.mah.se/upload/ Forskningscentrum/MIM/Publications/CT\%2015\%20Current $\% 20$ Themes $\% 2015 \% 20$ muep.pdf.

Emilsson, H. (2016). Recruitment to Occupations with a Surplus of Workers: The Unexpected Outcomes of Swedish Demand-Driven Labour Migration Policy, International Migration 54(2), 5-17, doi: http://dx.doi.org/10.1111/imig.12222.

Government bill (Proposition) 2007/2008. Stockholm: Government of Sweden. 
HRF (2012): Till vilket pris som helst? [At any cost?]. Stockholm: HRF.

Johansson, J. (2014). Swedish Employers and Trade Unions, Labor Migration and the Welfare State, Nordic Journal of Working Life Studies 4(1), 97-118, doi: http://dx.doi. org/10.19154/njwls.v4i1.3554.

LO (2013). Fusk och utnyttjande - om avregleringen av arbetskraftsinvandringen [Cheating and exploitation - about deregulation of labor immigration]. Stockholm: LO, URL: http:// www.lo.se/home/lo/res.nsf/vRes/lo fakta 1366027478784 fusk och utnyttjande pdf/\$File/Fusk och utnyttjande.pdf.

Migration Agency (Migrationsverket) (2013). Yttrande rörande förslaget om åtgärder mot missbruk av reglerna för arbetskraftsinvandring [Opinion on the proposal on action against abuse of the rules for labour immigration]. (Ds 2013:57).

OECD (2011). Recruiting Immigrant Workers: Sweden 2011. OECD Publishing, URL: http://www.oecd-ilibrary.org/docserver/download/8111191e.pdf?expires=1499889667 \&id=id\&accname $=$ ocid177253\&checksum $=877938$ F1C70E048E054E34482DB8FE08.

OECD (2015). International Migration Outlook 2015. OECD Publishing, URL: http://www. oecd-ilibrary.org/docserver/download/8115161e.pdf? expires=1499889764\&id=id\&accname=ocid177253\&checksum=CFCB05B0D6D4FD515895B71192D4FCE0.

Ollus, N. (2016). Forced Flexibility and Exploitation: Experiences of Migrant Workers in the Cleaning Industry, Nordic Journal of Working Life Studies 6(1), 25-45, doi: http://dx.doi. org/10.19154/njwls.v6i1.4908.

Ollus, N. and Jokinen, A (2013). "We've got people lined up behind the Door": Placing the Trafficking and Exploitation of Migrant Workers in the Context in the Restaurant and Cleaning Sectors in Finland. In Ollus, N. et al (2013), 31-170.

Ollus, N., Jokinen, A. and Joutsen, M. (eds. 2013) Exploitation of migrant workers in Finland, Sweden, Estonia and Lithuania. Helsinki: HEUNI, URL: http://www.cbss.org/ wp-content/uploads/2012/11/HEUNI-report-75-15102013.pdf.

Pelling, L. (2015). Fristad Sverige? [Sanctuary Sweden?]. In Calleman C. and Herzfeld Olsson P. (2015), 244-289.

Portes, A. (2010). Economic Sociology. New Jersey: Princeton University Press.

Refslund, B. and Thörnquist, A. (2016). Intra-European labour migration and low-wage competition - comparing the Danish and Swedish experiences across three sectors, Industrial Relations Journal 47(1), 62-78, doi: http://dx.doi.org/10.1111/irj.12126.

Urban, S. (2013). Restaurant work experience as stepping stone to the rest of labour market, Nordic Journal of Migration Research, 3(2), 100-109, doi: http://dx.doi.org/10.2478/ v10202-012-0020-x.

Vogiazides, L. and Hedberg, C. (2013). Trafficking for forced labour and labour exploitation in Sweden: Examples from the Restaurant and the Berry Industries. In Ollus, N. et al (2013), 171-237. 